\title{
IN VITRO ACTIVITY AND COMPARATIVE STUDIES OF SOME ORGANOTIN(IV) BENZOATE DERIVATIVES AGAINST LEUKEMIA CANCER CELL, L-1210
}

\author{
Sutopo Hadi*, Mita Rilyanti, and Suharso \\ Department of Chemistry, University of Lampung, Bandar Lampung 35145 Indonesia
}

Received November 28, 2011; Accepted February 27, 2012

\begin{abstract}
A series of dibutyl-, diphenyl- and triphenyltin(IV) benzoate derivatives has been prepared. The products were obtained by reacting the dibutyltin(IV) dichloride, diphenyltin(IV) dichloride and triphenyltin(IV) chloride respectively via the dibutyltin(IV) oxide, diphenyltin(IV) dihydroxide and triphenyltin(IV) hydroxide with benzoate acid and its derivative. The targeted compounds have been tested with anticancer activity against leukemia cancer cell, L-1210. The compounds synthesized were well characterized by ${ }^{1} \mathrm{H}$ and ${ }^{13} \mathrm{C}-\mathrm{NMR}$, IR and UV-Vis spectroscopies as well as based on the microanalytical data. The results showed that triphenyltin(IV) benzoate and its derivative prepared exhibit higher anticancer activity than those of dibutyltin(IV) and diphenyltin(IV) analogous.
\end{abstract}

Keywords: anticancer; $I C_{50}$; leukemia cancer cell; organotin(IV) benzoates

\section{ABSTRAK}

Telah dibuat seri senyawa dibutil-, difenil- dan trifeniltimah(IV) dengan asam benzoat dan turunannya. Senyawa hasil diperoleh dengan mereaksikan berturut-turut dibutiltimah(IV) diklorida, difeniltimah(IV) diklorida dan trifeniltimah(IV) klorida melalui senyawa antara dibutiltimah(IV) oksida, difeniltimah(IV) dihidroksida dan trifeniltimah(IV) hidroksida dengan asam benzoat dan turunannya. Senyawa-senyawa yang dihasilkan kemudian diuji aktifitas antikankernya terhadap sel kanker leukemia L-1210. Senyawa-senyawa hasil sintesis dikarakterisasi dengan spektroskopi NMR ${ }^{1} \mathrm{H}$ dan ${ }^{13} \mathrm{C}$, IR dan UV sinar tampak dan juga berdasarkan data mikroanalisis. Hasil penelitian menunjukkan bahwa senyawa trifeniltimah(IV) benzoat dan turunannya memberikan hambatan tertinggi pada uji antikanker dibandingkan senyawa sejenis dari dibutiltimah(IV) dan difeniltimah(IV).

Kata Kunci: antikanker; $I_{50}$; sel kanker leukemia; organotimah(IV) benzoat

\section{INTRODUCTION}

The structural chemistry of organotin carboxylates has attracted much attention due to their significant cytotoxic effect and relatively high antitumor activity [1-2]. The new development of these compound may lead for the development of new antitumor drugs, which can display another spectrum of antitumor activity $[1,3]$. The organotin(IV) compounds are known to display strong biological activity. Their compounds are normally exhibiting high toxicity, even at very low concentration. Their biological activities are fundamentally determined by the number and the nature of organic groups bound to the central $\mathrm{Sn}$ atom [4]. The nature of the anionic groups seems acting only as a secondary factor.

The current investigations on the coordinating properties of carboxylates toward organotin compounds have led to the isolation of some new organotin(IV) carboxylates and carboxylate derivatives which have shown some interesting biological activities such as antimicrobial [5-6], antitumor and anticancer [1,3,7-9], and antifungal activity [6,10-12]. The investigation of organotin(IV) as possible antitumor compound has been and is still attracting much attention [1,3,7-9].

In the present work, we reported application, comparative and in vitro activity study of some dibutyl-, diphenyl- and triphenyltin(IV) benzoate and its derivatives against leukemia cancer cell, L-1210.

\section{EXPERIMENTAL SECTION}

\section{Materials}

All reagents used were AR grade. Dibutyltin(IV) dichlorides $\left(\left[\left(n-\mathrm{C}_{4} \mathrm{H}_{9}\right)_{2} \mathrm{Cl}_{2}\right]\right)$, diphenyltin(IV) dichloride $\left(\left[\left(\mathrm{C}_{6} \mathrm{H}_{5}\right)_{2} \mathrm{Cl}_{2}\right]\right)$, triphenyltin(IV) chloride $\left(\left[\left(\mathrm{C}_{6} \mathrm{H}_{5}\right)_{3} \mathrm{Cl}\right]\right)$, benzoic acid, 2-hydroxybenzoic acid, sodium hydroxide $(\mathrm{NaOH})$, methanol $\left(\mathrm{CH}_{3} \mathrm{OH}\right)$ were either Sigma or JT Baker products, and were used without further purification. The leukemia cancer cells, L-1210, were obtained from Center for Application of Isotopes and

* Corresponding author.

Email address : sutopohadi@unila.ac.id 
Radiation Technology, National Agency of Atomic Energy, Pasar Jumat, Jakarta, Indonesia.

\section{Instrumentation}

Elemental analysis (CHNS) was performed on Fision EA 1108 series elemental analyzer. IR spectra in the range of $4000-400 \mathrm{~cm}^{-1}$ were recorded on a Bruker VERTEX $70 \mathrm{FT}-\mathrm{IR}$ spectrophotometer with $\mathrm{KBr}$ discs. The UV spectra were recorded in the UV region and were measured using a UV-Shimadzu UV-245 Spectrophotometer. Measurements were performed in $1 \mathrm{~mL}$ quartz-cells. Solutions were prepared using methanol as the solvent with concentration of $1.0 \times 10^{-4} \mathrm{M} .{ }^{1} \mathrm{H}$ and ${ }^{13} \mathrm{C}$ NMR spectra were recorded on a Bruker AV $600 \mathrm{MHz}$ NMR $\left(600 \mathrm{MHz}\right.$ for ${ }^{1} \mathrm{H}$ and 150 $\mathrm{MHz}$ for ${ }^{13} \mathrm{C}$ ). All experiments were run in $\mathrm{DMSO}^{-\mathrm{D}_{6}}$ at $298 \mathrm{~K}$. The number of runs used for ${ }^{1} \mathrm{H}$ experiments were 32 with reference at DMSO signal at $2.5 \mathrm{ppm}$, while the ${ }^{13} \mathrm{C}$ were $1000-4000$ scans with the reference DMSO signal at $39.5 \mathrm{ppm}$.

\section{Procedure}

\section{Preparation of organotin(IV) carboxylates}

The organotin(IV) carboxylates used in this work and similar compounds with variety of benzoic derivatives as the ligands were prepared based on the procedure previously reported [9,11-12], and was adapted from the work by Szorcsik et al. [13]. An example procedure in the preparation of dibutyltin(IV) dibenzoate is as follows:

To $3.0383 \mathrm{~g}(0.01 \mathrm{~mol})\left[\left(n-\mathrm{C}_{4} \mathrm{H}_{9}\right)_{2} \mathrm{SnCl}_{2}\right]$ in $50 \mathrm{~mL}$ methanol was added $0.8 \mathrm{~g}(0.02 \mathrm{~mol}) \mathrm{NaOH}$. The reaction mixtures were stirred for about $45 \mathrm{~min}$. Compound $\mathbf{2}$ was precipitated out as white solid, filtered off and dried in vacuo till they are ready for analysis and further reaction. The average yield was $2.3508 \mathrm{~g}(95 \%)$.

To $0.37338 \mathrm{~g}(1.5 \mathrm{mmol})$ compound 2 in $50 \mathrm{~mL}$ of methanol was added with 2 mole equivalents of benzoic acid and was refluxed for $4 \mathrm{~h}$ at $60-70^{\circ} \mathrm{C}$. After removal of the solvent by rotary evaporator, the produced compounds $\left[\left(n-\mathrm{C}_{4} \mathrm{H}_{9}\right)_{2} \mathrm{Sn}(\mathrm{OOCR})_{2}\right]$ were dried in vacuo until they are ready for analysis and further use for biological test. The average yields were more than $\sim 90 \%$.

A similar procedure was also adapted in the preparation of diphenyltin(IV) and triphenyltin(IV) derivatives, $\left[\left(\mathrm{C}_{6} \mathrm{H}_{5}\right)_{2} \mathrm{Sn}(\mathrm{OOCR})_{2}\right]$ and $\left[\left(\mathrm{C}_{6} \mathrm{H}_{5}\right)_{3} \mathrm{Sn}(\mathrm{OOCR})\right]$, respectively. For triphenyltin(IV) only one mole equivalent of the carboxylic acid was added.

\section{Bioassay anticancer activity test against leukemia cancer cell, L-1210}

The in vitro anticancer activity test against leukemia cancer cell, L-1210 was performed based on the known procedure [9]. $1 \mathrm{~mL}$ of the cancer cells were added into each hole of multiwell plate tissue culture containing $2 \times 10^{6} \mathrm{cell} / \mathrm{mL}$ followed by the addition of $10 \mu \mathrm{L}$ of solution containing the compounds tested in methanol (if the sample was not soluble enough in the solvent used, before it is being added, the ultrasonic mixing was done first to homogenize the sample). The sample concentration variations used were $1,2,4,6,8$, $16,32 \mu \mathrm{g} / \mathrm{mL}$ and three replicates per concentration were performed. As the negative control, the cell was treated with a solution containing $10 \mu \mathrm{L}$ of solvent was used as comparison. The cell was then incubated for $48 \mathrm{~h}$ in $5 \% \mathrm{CO}_{2}$ incubator at $37{ }^{\circ} \mathrm{C}$. After being incubated, the sum of cell was counted in microscope using haemecytometer Fuch Rosental $(0.200 \mathrm{~mm}$ x $0.0625 \mathrm{~mm}^{2}$ ).

The percentage of inhibition was calculated using the following formula in Eq. (1):

$\%$ inhibiton $=\left(1-\frac{A}{B}\right) \times 100$

where $A$ is the number of lives cell in medium tested; and $B$ is the number of lives cell in control/blank.

\section{Calculation of $I C_{50}$}

The $\mathrm{IC}_{50}$ was calculated according to the adaption of Reed and Muench method which is an arithmetic method [14] and as following:

The data of all inhibition percentages were plotted into probit table to obtain each probit value of each analysis. The graph between log of concentration ( $x$ ) and probity value $(\mathrm{y})$ was then created to obtain a linier regression, $y=a+b x$. By inputting the probit value $(y)=5$ (the probit of $50 \%$ value), then the value of $x$ (log of concentration) was obtained. The $\mathrm{IC}_{50}$ value was then obtained by taking the anti log of $x$.

\section{RESULT AND DISCUSSION}

\section{Preparation and characterization of organotin(IV) carboxylate compounds}

The preparation of dibutyltin(IV) dicarboxylates, $\left[\left(n-\mathrm{C}_{4} \mathrm{H}_{9}\right)_{2} \mathrm{Sn}(\mathrm{OOCR})_{2}\right] \quad(3, \quad 4), \quad$ diphenyltin(IV) dicarboxylates $\left[\left(\mathrm{C}_{6} \mathrm{H}_{5}\right)_{2} \mathrm{Sn}(\mathrm{OOCR})_{2}\right] \quad(\mathbf{7}, \mathbf{8})$ and triphenyltin(IV) carboxylates, $\quad\left[\left(\mathrm{C}_{6} \mathrm{H}_{5}\right)_{3} \mathrm{Sn}(\mathrm{OOCR})\right]$ $(11,12)$, were successfully done from their chlorides $\left[\left(n-\mathrm{C}_{4} \mathrm{H}_{9}\right)_{2} \mathrm{SnCl}_{2}\right] \quad(\mathbf{1}), \quad\left[\left(\mathrm{C}_{6} \mathrm{H}_{5}\right)_{2} \mathrm{SnCl}_{2}\right] \quad$ (5) and $\left[\left(\mathrm{C}_{6} \mathrm{H}_{5}\right)_{3} \mathrm{SnCl}\right](\mathbf{9})$, respectively. To maximize the product 


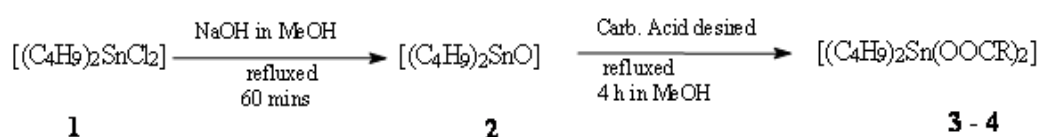

Fig 1. The scheme of preparative route of the organotin(IV) dicarboxylate<smiles>CCCCC[Sn]1(CCCC)OC(=O)c2ccccc2C(=O)O1</smiles>

3<smiles>O=C(O[Sn]1(c2ccccc2)OC(=O)c2ccccc21)c1ccccc1</smiles><smiles>O=C(O[Sn](c1ccccc1)(c1ccccc1)c1ccccc1)c1ccccc1</smiles>

11

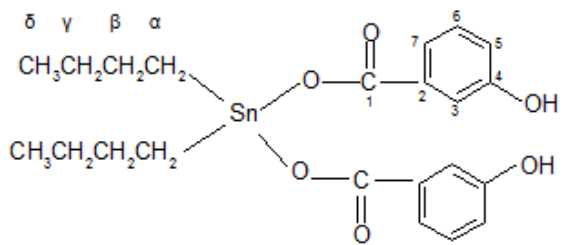

4<smiles></smiles>

8<smiles>O=C(O[Sn](c1ccccc1)(c1ccccc1)c1ccccc1)c1cccc(O)c1</smiles>

12

Fig 2. The proposed structure of the compounds synthesized and the suggested numbering of carbons in each compound

obtained, the reactions in all cases were done via [ $(n-$ $\left.\left.\mathrm{C}_{4} \mathrm{H}_{9}\right)_{2} \mathrm{SnO}\right](2),\left[\left(\mathrm{C}_{6} \mathrm{H}_{5}\right)_{2} \mathrm{Sn}(\mathrm{OH})_{2}\right](6)$ and $\left[\left(\mathrm{C}_{6} \mathrm{H}_{5}\right)_{3} \mathrm{SnOH}\right]$ (10) respectively similar to those previously reported [9,11-12]. The reaction occurred in each step for dibutyltin(IV) dicarboxylates, for example, is shown in Scheme 1. The microanalytical data of all compounds prepared are very good and all values obtained are close to the calculated values as shown in Table 1.

The characterizations of the targeted products synthesized were confirmed by some spectroscopy techniques. The ${ }^{1} \mathrm{H}$ and ${ }^{13} \mathrm{C}$ chemical shifts of the compounds prepared are shown Table 2. A number of signals in the spectra recorded have been characterized carefully. The chemical shift $(\delta)$ of butyl protons attached to the tin metal appeared in the range of $0.93 \mathrm{ppm}$ for $\mathrm{H} \delta$ up to 1.4-1.6 ppm $\mathrm{H \alpha}$ and $H \beta$, and the carbons of butyl ligands are observed at position comparable with other similar compounds reported by other [15]. The chemical shift of phenyl protons attached to tin metal appeared in the range of 7.6-7.36 ppm, while the carbon of carboxyl group of all compounds as expected appeared in the region of $174 \mathrm{ppm}[15,16]$. The carbon atoms of the phenyl ligand as also expected appeared in $\delta$ of
130-126 ppm, while the carbons in the benzoate derivatives appeared in $\delta$ range of 139-129 ppm close to the reported values of similar compounds [16].

The important FT-IR data and their assignments are presented in Table 3. The characteristic band of the starting materials $(\mathbf{1}, \mathbf{5}, \mathbf{9})$ is the appearance of strong stretching band of $\mathrm{Sn}-\mathrm{Cl}$ bond at $390-310 \mathrm{~cm}^{-1}$. As an example in the spectrum of 1 , this bond appeared at frequency of $334.2 \mathrm{~cm}^{-1}$. The other characteristic bands of this compound appear as stretching band from butyl ligands at $1069 \mathrm{~cm}^{-1}$, and bending vibration of $\mathrm{C}-\mathrm{H}$ aliphatic stretch of the butyl at frequency of 2956-2865 $\mathrm{cm}^{-1}$.

When compound $\mathbf{1}$ is converted to compound $\mathbf{2}$, the main stretching band of $\mathrm{Sn}-\mathrm{Cl}$ disappeared and a new strong band at frequency of $417.4 \mathrm{~cm}^{-1}$ appeared as one of the main stretching band. This band is characteristic for $\mathrm{Sn}-\mathrm{O}$ bond in compound [ $n$ $\left.\mathrm{C}_{4} \mathrm{H}_{9}\right)_{2} \mathrm{SnO}$ ] (2). The stretching band due to the butyls and their bending vibrations are still appearing as expected although the frequencies have little bit shifted. The formation of dibutyltin (IV) dicarboxylate compounds, $\left[\left(n-\mathrm{C}_{4} \mathrm{H}_{9}\right)_{2} \mathrm{Sn}(\mathrm{RCOO})_{2}\right],(\mathbf{3}, \mathbf{4})$ is confirmed 
Table 1. The microanalytical data of the organotin(IV) compounds synthesized

\begin{tabular}{|c|c|c|}
\hline \multirow[t]{2}{*}{ Compound } & \multicolumn{2}{|c|}{$\begin{array}{l}\text { Elemental analysis found } \\
\text { (calculated) }\end{array}$} \\
\hline & $\mathrm{C}$ & $\mathrm{H}$ \\
\hline$\left[\left(n-\mathrm{C}_{4} \mathrm{H}_{9}\right)_{2} \mathrm{SnCl}_{2}\right](\mathbf{1})$ & $31.4(31.6)$ & $6.2(6.0)$ \\
\hline$\left[\left(n-\mathrm{C}_{4} \mathrm{H}_{9}\right)_{2} \mathrm{SnO}\right](2)$ & $38.6(38.6)$ & $7.2(7.3)$ \\
\hline$\left[\left(n-\mathrm{C}_{4} \mathrm{H}_{9}\right)_{2} \mathrm{Sn}\left(\mathrm{C}_{6} \mathrm{H}_{5} \mathrm{COO}\right)_{2}\right](3)$ & $55.1(55.6)$ & $5.9(6.0)$ \\
\hline$\left[\left(n-\mathrm{C}_{4} \mathrm{H}_{9}\right)_{2} \mathrm{Sn}\left(\mathrm{o}-\mathrm{C}_{6} \mathrm{H}_{4}(\mathrm{OH}) \mathrm{COO}\right)_{2}\right](4)$ & $52.3(52.1)$ & $5.7(5.6)$ \\
\hline$\left[\left(\mathrm{C}_{6} \mathrm{H}_{5}\right)_{2} \mathrm{SnCl}_{2}\right](5)$ & $41.6(41.9)$ & $2.8(2.9)$ \\
\hline$\left[\left(\mathrm{C}_{6} \mathrm{H}_{5}\right)_{2} \mathrm{Sn}(\mathrm{OH})_{2}\right](\mathbf{6})$ & $46.5(46.9)$ & $3.8(3.9)$ \\
\hline$\left[\left(\mathrm{C}_{6} \mathrm{H}_{5}\right)_{2} \mathrm{Sn}\left(\mathrm{C}_{6} \mathrm{H}_{5} \mathrm{COO}\right)_{2}\right](7)$ & $60.4(60.6)$ & $3.6(3.7)$ \\
\hline$\left[\left(\mathrm{C}_{6} \mathrm{H}_{5}\right)_{2} \mathrm{Sn}\left(\mathrm{O}-\mathrm{C}_{6} \mathrm{H}_{4}(\mathrm{OH}) \mathrm{COO}\right)_{2}\right](8)$ & $56.3(57.0)$ & $3.6(3.7)$ \\
\hline$\left[\left(\mathrm{C}_{6} \mathrm{H}_{5}\right)_{3} \mathrm{SnCl}\right](\mathbf{9})$ & $55.8(56.1)$ & $4.0(3.9)$ \\
\hline$\left[\left(\mathrm{C}_{6} \mathrm{H}_{5}\right)_{3} \mathrm{Sn}(\mathrm{OH})\right](10)$ & $58.4(58.9)$ & $4.3(4.4)$ \\
\hline$\left[\left(\mathrm{C}_{6} \mathrm{H}_{5}\right)_{3} \mathrm{Sn}\left(\mathrm{C}_{6} \mathrm{H}_{5} \mathrm{COO}\right)\right](11)$ & $63.9(63.7)$ & $4.4(4.3)$ \\
\hline $\left.\mathrm{Sn}\left(\mathrm{O}-\mathrm{C}_{6} \mathrm{H}_{4}(\mathrm{OH}) \mathrm{COO}\right)\right](12)$ & $60.7(61.1)$ & $4.2(4.1)$ \\
\hline
\end{tabular}

Table 2. ${ }^{1} \mathrm{H}$ and ${ }^{13} \mathrm{C}$ spectra of the compounds synthesized

\begin{tabular}{|c|c|c|c|}
\hline Compounds & $\begin{array}{l}\mathbf{H} \text { in butyl or } \\
\text { phenyl (ppm) }\end{array}$ & $\begin{array}{l}\mathbf{H} \text { in benzoate } \\
(\mathrm{ppm})\end{array}$ & $\begin{array}{c}\text { C in butyl, phenyl and benzoate } \\
\text { (ppm) }\end{array}$ \\
\hline$\left[\left(n-\mathrm{C}_{4} \mathrm{H}_{9}\right)_{2} \mathrm{Sn}\left(\mathrm{OOCC}_{6} \mathrm{H}_{5}\right)_{2}\right](3)$ & $\begin{array}{c}\mathrm{H \alpha} \& H \beta: 1.4-1.6 \\
(\mathrm{~m}) ; \mathrm{Hy}: 1.29(\mathrm{~m}) \\
\mathrm{H} \delta: 0.93(\mathrm{t})\end{array}$ & $7.35-7.85(\mathrm{~m})$ & $\begin{array}{c}\text { Ca: 21.3; Cß: 26.6; Cү: 25.9; Cठ: } \\
\text { 14.2; C1: 174.2; C2: 139.3; C3 \& } \\
\text { C7: 129.7; C4 \& C6: 128.6; C5: } \\
125.1\end{array}$ \\
\hline$\left[\left(n-\mathrm{C}_{4} \mathrm{H}_{9}\right)_{2} \mathrm{Sn}\left(\mathrm{o}-\mathrm{C}_{6} \mathrm{H}_{4}(\mathrm{OH}) \mathrm{COO}\right)_{2}\right](4)$ & 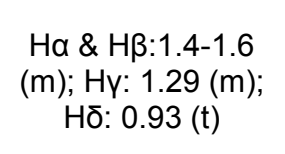 & 7.35-7.89 (m) & $\begin{array}{c}\text { Ca: 21.3; Cß: 26.7; Cү: 25.9; Cర: } \\
\text { 14.3; C1: 174.2; C2: 139.3; C3: } \\
\text { 130.1; C4: 164.6; C5: } 129.5 ; \text { C6: } \\
\text { 128.9; C7: } 129.9\end{array}$ \\
\hline$\left[\left(\mathrm{C}_{6} \mathrm{H}_{5}\right)_{2} \mathrm{Sn}\left(\mathrm{OOCC}_{6} \mathrm{H}_{5}\right)_{2}\right](7)$ & $\begin{array}{c}\mathrm{H} 2 \text { \& } \mathrm{H} 67.59(\mathrm{~d} \\
4 \mathrm{H}) ; \mathrm{H} 3 \text { \& } \mathrm{H} 57.48 \\
(\mathrm{t}, 4 \mathrm{H}) ; \mathrm{H} 4: 7.35 \\
(\mathrm{t}, 2 \mathrm{H})\end{array}$ & 7.81-7.94 (m) & $\begin{array}{l}\text { C1-6 (phen): 131.7-126.9; C7: } \\
\text { 174.7; C8: 139.5; C9 \& C13: 130.2; } \\
\text { C10 \& C12: 129.1; C11: } 128.5\end{array}$ \\
\hline$\left[\left(\mathrm{C}_{6} \mathrm{H}_{5}\right)_{2} \mathrm{Sn}\left(\mathrm{o}-\mathrm{C}_{6} \mathrm{H}_{4}(\mathrm{OH}) \mathrm{COO}\right)_{2}\right](8)$ & $\begin{array}{c}\mathrm{H} 2 \& \mathrm{H} 67.58(\mathrm{~d} \\
4 \mathrm{H}) ; \mathrm{H} 3 \& \mathrm{H} 57.48 \\
(\mathrm{t}, 4 \mathrm{H}) ; \mathrm{H} 47.36(\mathrm{t}, \\
2 \mathrm{H})\end{array}$ & 7.89-7.99 (m) & $\begin{array}{c}\text { C1-6 (phen): 131.7-126.9; C7: } \\
\text { 174.9; C8: 139.8; C9: 130.4; C10: } \\
\text { 164.9; C11: 129.7; C12: 129.0; } \\
\text { C13: } 130.2\end{array}$ \\
\hline$\left[\left(\mathrm{C}_{6} \mathrm{H}_{5}\right)_{3} \mathrm{Sn}\left(\mathrm{OOCC}_{6} \mathrm{H}_{5}\right)\right](11)$ & $\begin{array}{c}\mathrm{H} 2 \text { \& H6 } 7.57(\mathrm{~d} \\
6 \mathrm{H}) ; \mathrm{H} 3 \text { \& H5 } 7.45 \\
(\mathrm{t}, 6 \mathrm{H}) ; \mathrm{H} 4: 7.31 \\
(\mathrm{t}, 3 \mathrm{H})\end{array}$ & $7.81-7.89(d)$ & $\begin{array}{l}\text { C1-6 (phen): 131.1-126.2; C7: } \\
\text { 174.4; C8: 139.3; C9 \& C13: 130.1; } \\
\text { C10 \& C12: 128.7; C11: } 128.2\end{array}$ \\
\hline$\left[\left(\mathrm{C}_{6} \mathrm{H}_{5}\right)_{3} \mathrm{Sn}\left(\mathrm{o}-\mathrm{C}_{6} \mathrm{H}_{4}(\mathrm{OH}) \mathrm{COO}\right)\right](12)$ & $\begin{array}{c}\mathrm{H} 2 \& \mathrm{H} 67.57(\mathrm{~d} \\
6 \mathrm{H}) ; \mathrm{H} 3 \text { \& H5 } 7.45 \\
(\mathrm{t}, 6 \mathrm{H}) ; \mathrm{H} 4: 7.31 \\
(\mathrm{t}, 3 \mathrm{H})\end{array}$ & $7.86-7.92(d)$ & $\begin{array}{c}\text { C1-6 (phen): 131.1-126.2; C7: } \\
\text { 174.8; C8: 139.6; C9: 130.1; C10: } \\
\text { 164.2; C11: 129.3; C12: 128.7; } \\
\text { C13: } 129.8\end{array}$ \\
\hline
\end{tabular}

by the strong asymmetric stretching bands of the carboxylates which occurred at ca. $1400 \mathrm{~cm}^{-1}$ and the symmetric stretch at ca. $1600 \mathrm{~cm}^{-1}$, confirming the success of the substitution reaction [9,11-12].

The UV-Vis spectroscopy analyses have also been taken for all the compounds used. The $\lambda_{\max }$ of all the compounds is summarized in Table 4. From the data obtained (Table 3 ), it is clear that there was a shifting change in the $\lambda_{\max }$ for each compound in any steps of the reaction. For example, the compound 1 has $\lambda_{\max }$ of $210.7 \mathrm{~nm}$, while compound 2 has $\lambda_{\max }$ of $202.9 \mathrm{~nm}$. This information gave an indication that there was a shift to a shorter $\lambda_{\max }$ value when the conversion of compound 1 to 2 takes place. The wave-length shift to a shorter $\lambda_{\max }$ could occur due to either the solvent used or the effect of an auxochrome. However in this study, as the solvent used for all measurements was the same (methanol), these changes must be due to the auxochrome effect. In the case of compound $\mathbf{1}$ and $\mathbf{2}$, there is an oxide group which has electron drawing effect bigger in compound 2 than that of chloride group in 1. As a result, the electron transition in $\mathbf{2}$ is hard to occur. Thus, the measured $\lambda_{\max }$ was getting shorter in compound 2 than in compound 1 [17]. Similar results are also observed for other changes as can be seen from Table 3. For example, in compound 3, the electron drawing effect of $o-\mathrm{C}_{6} \mathrm{H}_{4}(\mathrm{OH}) \mathrm{COOH}$ is less than 
Table 3. The characteristic and important IR bands of the organotin(IV) compounds $\left(\mathrm{cm}^{-1}\right)$ synthesized

\begin{tabular}{cccccccc}
\hline Compound & $\mathbf{3}$ & $\mathbf{4}$ & $\mathbf{7}$ & $\mathbf{8}$ & $\mathbf{1 1}$ & $\mathbf{1 2}$ & References \\
\hline $\mathrm{Sn}-\mathrm{O}$ & 434.5 & 435.7 & 594.7 & 591.6 & 765.59 & 755.41 & $800-400$ \\
$\mathrm{Sn}-\mathrm{O}-\mathrm{C}$ & 1029.9 & 1028.1 & 1243.4 & 1290.1 & 1243.36 & 1298.7 & $1050-900$ \\
$\mathrm{Sn}-\mathrm{Bu}$ & 674.8 & 678.3 & - & - & - & - & $740-660$ \\
$\mathrm{CO}_{2}$ asym & 1419.6 & 1418.2 & 1532.9 & 1596.8 & 1558.8 & 1562.3 & $1600-1400$ \\
$\mathrm{CO}_{2}$ sym & 1558.7 & 1560.7 & 1660.8 & 1690.2 & 1631.36 & 1698.74 & $1700-1550$ \\
$\mathrm{C}-\mathrm{H}$ aliphatic & $2955-2862$ & $2955-2866$ & - & - & - & - & $2960-2850$ \\
Phenyl & - & - & $1467.6 ; 751.3$ & $1490.8 ; 725.2$ & $1428.7 ; 729.64$ & $1430.2 ; 729.53$ & 1450,730 \\
\hline
\end{tabular}

Table 4. The $\lambda_{\max }$ of the UV-Vis spectra of the organotin(IV) compounds

\begin{tabular}{lc}
\hline Compound & $\lambda_{\max }(\mathrm{nm})$ \\
\hline$\left[\left(n-\mathrm{C}_{4} \mathrm{H}_{9}\right)_{2} \mathrm{SnCl}\right](\mathbf{1})$ & 210.7 \\
{$\left[\left(n-\mathrm{C}_{4} \mathrm{H}_{9}\right)_{2} \mathrm{SnO}\right](\mathbf{2})$} & 202.9 \\
{$\left[\left(n-\mathrm{C}_{4} \mathrm{H}_{9}\right)_{2} \mathrm{Sn}\left(\mathrm{C}_{6} \mathrm{H}_{5} \mathrm{COO}\right)_{2}\right](3)$} & 302.3 \\
{$\left[\left(n-\mathrm{C}_{4} \mathrm{H}_{9}\right)_{2} \mathrm{Sn}\left(o-\mathrm{C}_{6} \mathrm{H}_{4}(\mathrm{OH}) \mathrm{COO}\right)_{2}\right](\mathbf{4})$} & 307.8 \\
{$\left[\left(\mathrm{C}_{6} \mathrm{H}_{5}\right)_{2} \mathrm{Sn}\left(\mathrm{C}_{6} \mathrm{H}_{5} \mathrm{COO}\right)_{2}\right](7)$} & 283.6 \\
{$\left[\left(\mathrm{C}_{6} \mathrm{H}_{5}\right)_{2} \mathrm{Sn}\left(o-\mathrm{C}_{6} \mathrm{H}_{4}(\mathrm{OH}) \mathrm{COO}\right)_{2}\right](\mathbf{8})$} & 287.7 \\
{$\left[\left(\mathrm{C}_{6} \mathrm{H}_{5}\right)_{3} \mathrm{Sn}\left(\mathrm{C}_{6} \mathrm{H}_{5} \mathrm{COO}\right)\right](11)$} & 298.9 \\
{$\left[\left(\mathrm{C}_{6} \mathrm{H}_{5}\right)_{3} \mathrm{Sn}\left(o-\mathrm{C}_{6} \mathrm{H}_{4}(\mathrm{OH}) \mathrm{COO}\right)\right](\mathbf{1 2})$} & 302.3 \\
\hline
\end{tabular}

Table 5. $\mathrm{IC}_{50}$ values of all compounds tested

\begin{tabular}{lc}
\hline Compounds & $\mathrm{IC}_{50}(\mu \mathrm{g} / \mathrm{mL})$ \\
\hline$\left[\left(n-\mathrm{C}_{4} \mathrm{H}_{9}\right)_{2} \mathrm{Sn}\left(\mathrm{C}_{6} \mathrm{H}_{5} \mathrm{COO}\right)_{2}\right](3)$ & 19.6 \\
{$\left[\left(n-\mathrm{C}_{4} \mathrm{H}_{9}\right)_{2} \mathrm{Sn}\left(\mathrm{o}_{-}-\mathrm{C}_{6} \mathrm{H}_{4}(\mathrm{OH}) \mathrm{COO}\right)_{2}\right](4)$} & 24.4 \\
{$\left[\left(\mathrm{C}_{6} \mathrm{H}_{5}\right)_{2} \mathrm{Sn}\left(\mathrm{C}_{6} \mathrm{H}_{5} \mathrm{COO}\right)_{2}\right](\mathbf{7})$} & 9.2 \\
{$\left[\left(\mathrm{C}_{6} \mathrm{H}_{5}\right)_{2} \mathrm{Sn}\left(0-\mathrm{C}_{6} \mathrm{H}_{4}(\mathrm{OH}) \mathrm{COO}\right)_{2}\right](\mathbf{8})$} & 10.3 \\
{$\left[\left(\mathrm{C}_{6} \mathrm{H}_{5}\right)_{3} \mathrm{Sn}\left(\mathrm{C}_{6} \mathrm{H}_{5} \mathrm{COO}\right)\right](11)$} & 5.3 \\
{$\left[\left(\mathrm{C}_{6} \mathrm{H}_{5}\right)_{3} \mathrm{Sn}\left(0-\mathrm{C}_{6} \mathrm{H}_{4}(\mathrm{OH}) \mathrm{COO}\right)\right](12)$} & 3.8 \\
\hline
\end{tabular}

chloride in $\mathbf{1}$, so the electron transition in this molecule will be easier (the energy required is less), thus producing longer $\lambda_{\max }, 307.8 \mathrm{~nm}$.

The antifungal activity of diorganotin(IV) and triorganotin(IV) compounds are well known, and many of their compounds have been synthesized for that purpose [6,10-12]. Some of the organotin(IV) compounds prepared have also been tested for antitumor activity and showed quite high antitumor activity [1,3,7-9].

In our previous study on the antifungal activity of the compounds reported here [11-12], it has been shown that optimal activity of the antifungal has been associated with the number of carbon atoms present in the organotin(IV) used [18], where in general, the derivative of triphenyltin(IV) carboxylate which contain 18 carbon atoms has smallest minimum inhibition concentration values in the series [11-12]. In this study interestingly the same phenomena was also observed.

Based on the data in Table 5, the derivatives of triphenyltin(IV) compounds has smaller $\mathrm{IC}_{50}$ value in the series, and the diphenyltin(IV) compound has smaller $\mathrm{IC}_{50}$ value than those of dibutyltin(IV) compounds. Thus the number of carbon atoms present has effect on the anticancer activity of the organotin(IV) tested. Besides that, the organotin(IV) carboxylate compounds synthesized have smaller $\mathrm{IC}_{50}$ values compare to those of starting materials and intermediate products. In this respect, our results are consistent with a well-known fact that many biologically active compounds become more active upon complexation than in their uncomplexed forms [19]. According to Crowe [20] the actual biological activity of diorganotin compounds of the type RR'SnXY (R and R' = alkyl or aryl; $X$ and $Y=$ anions) is determined solely by the $\mathrm{RR}^{\prime} \mathrm{Sn}^{2+}$ moiety. Consequently the group $X$ and $Y$ would only influence the delivery of the active RR' $\mathrm{Sn}^{2+}$ ion to the cell, although it is not clear enough how is their mechanism of action.

\section{CONCLUSION}

It is quite clear from the discussion above that some promising organotin(IV) carboxylate compounds were successfully prepared and exhibited very high in vitro anticancer activity. The study of other organotin(IV) series which might have higher and better anticancer activity is still in progress. The in vivo testing of the compounds synthesized against human cancer will also be undertaken to evaluate their possible use as an anticancer metal base-drug in the future.

\section{ACKNOWLEDGEMENT}

The authors would like to thank to The Directorate of Research and Services, Directorate General of Higher Education, The Ministry of Cultural and Education of Republic of Indonesia that provide fund for this project to be undertaken through Hibah Kompetensi Batch 2 Research Grant Scheme 2009 and 2011 with contract numbers of 254/SP2H/PP/DP2M/V/2009 and 364/SP2H/PL/Dit. Litabmas/IV/2011, respectively. Thanks also go to Prof. Bohari M. Yamin, Universiti Kebangsaan Malaysia for helping in doing microanalysis and Dr. Huy Hoang of Institute of Molecular Biosciences (IMB) University of Queensland, Brisbane, Australia for NMR experimentation.

\section{REFERENCES}

1. Nath, M., Pokharia, S., and Yadav, R., 2001, Coord. Chem. Rev., 215, 99-149. 
2. Gielen, M., 2003, J. Braz. Chem. Soc., 14, 6, 870877.

3. Zhang, Z-W., Jiang, T., Ren, S-M., Zhang, Y-X., and Yu, J-S., 2005, Chin. J. Chem., 23, 12, 1655-1658.

4. Pellerito, L., and Nagy, L., 2002, Coord. Chem. Rev., 224, 111-150.

5. Bonire, J.J., Ayoko, G.A., Olurinola, P.F., Ehinmidu, J.O., Jalil, N.S.N., and Omachi, A.A., 1998, Met.Based Drugs, 5, 4, 233-236.

6. Mahmood, S., Ali, S., Bhatti, M.H., Mazhar, M., and Iqbal, R., 2003, Turk. J. Chem., 27, 6, 657-666.

7. Li, Y., Li, Y., Niu, Y., Jie, L., Shang, X., Guo, J., and Li, Q., 2008, J. Bioinorg. Chem., 102, 9, 1731-1735.

8. Rehman, W., Badshah, A., Khan, S., and Tuyet, L.T.A., 2009, Eur. J. Med. Chem., 44, 10, 39813985.

9. Hadi, S., and Rilyanti, M., 2010, Orient. J. Chem., 26, 3, 775-779.

10. Ruzika, A., Dostal, L., Jambor, R., Butcha, V., Brus, J., Cisarova, I., Holcapek, M., and Holecek, J., 2002, Appl. Organomet. Chem., 16, 6, 315-322.
11. Hadi, S., Irawan, B., and Efri, 2008, J. Appl. Sci. Res., 4, 11, 1521-1525.

12. Hadi, S., Rilyanti, M., and Nurhasanah, 2009, Mod. Appl. Sci., 3, 1, 12-17.

13. Szorcsik, A., Nagy, L., Gadja-Schrantz, K., Pellerito, L., Nagy, E., and Edelmann, E.T., 2002, J. Radioanal. Nucl. Chem., 252, 3, 523-530.

14. Turner, R.A., 1972, Screening Methods In Pharmacology, New York, Academic Press, 60-72.

15. Nath, M., Yadav, R., Gielen, M., Dalil, H., de Vos, D., and Eng, G., 1997, Appl. Organomet.. Chem., 11, 727-736.

16. Li, Q., da Silva, F.M.C.G., and Pombeiro, A.J.L., 2004, Chem. Eur. J., 10, 6, 1456-1462.

17. Sudjadi, 1985, The Structure Determination of Organic Compounds, Ghalia Publishers, Indonesian, 327.

18. Chohan, Z.H., and Rauf, A., 1996, Synth. React. Inorg. Met.-Org. Chem., 26, 4, 591-604.

19. Gershon, H., 1974, J. Med. Chem., 17, 8, 824-827.

20. Crowe, A.J., 1989, Met.-Based Drugs, 1, 103-149. 